\title{
Electron Microprobe Analysis in Guided Tissue Regeneration: A Case Report
}

\author{
Maximino González-Jaranay ${ }^{a}$ \\ María del Carmen Sánchez-Quevedo ${ }^{b}$ \\ Gerardo Moreu \\ José Manuel García \\ Antonio Campos ${ }^{b}$
}

\section{ABSTRACT}

Objectives: Several procedures have been advocated as regenerative procedures in periodontology, but one of the most widely used techniques up to now is guided tissue regeneration (GTR). Likewise, different assessment methods based on clinical, radiographic or histological measurements have been proposed for the evaluation of these regenerative procedures. However, none of the methods used for human material incorporates quantitative X-ray microanalysis to assess the degree of mineralization of the regenerated periodontal hard tissues. The objective of this report was to evaluate, using quantitative X-ray microprobe analysis, the newly-formed hard tissue in a periodontal infrabony defect.

Methods: Electron microprobe analysis was used to study the nature of the newly-formed hard tissue 3 years after treatment with guided tissue regeneration in a patient with localized aggressive periodontitis.

Results: Our quantitative analyses, using the peak-to-background method, showed calcium/phosphorus mass ratio of $1.50 \pm 0.38$ in the newly-formed hard tissue around the affected tooth root.

Conclusion: Quantitative X-ray microprobe analysis is a useful tool that may provide an accurate assessment of the degree of mineralization in an extremely small tissue sample. (Eur J Dent 2007;1:4044)

Keywords: Guided tissue regeneration; Bone regeneration; Periodontal regeneration; Quantitative X-ray microprobe analysis; Mineralization.

\section{INTRODUCTION}

Regeneration is defined as a reproduction or reconstitution of a lost or injured part in such a way that the architecture and function of the lost or injured tissue are completely restored. ${ }^{1}$ Periodontal regeneration by GTR has been defined within the concept of "new attachment". ${ }^{2}$ The ultimate goal of a new attachment procedure should be to restore, on a diseased or traumatized root, the lost connective tissue attachment by a new cementum with inserting collagen fibers and, pref-

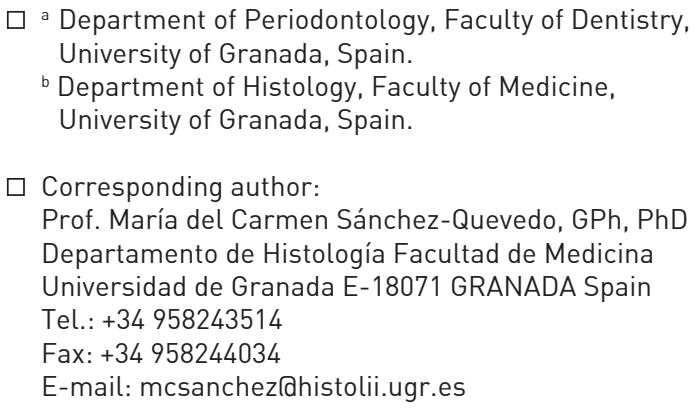

erably, the regrowth of new alveolar bone. Thus, although bone regrowth is not a prerequisite for a new attachment procedure, it is always a desirable outcome in order to satisfy the definition of regeneration. 3,4

Several surgical procedures have been proposed for periodontal regeneration, but one of the most widely employed current techniques is guided tissue regeneration (GTR), in which a membrane is placed between the soft tissue flap and the root surface to serve as a barrier which prevents the gingival tissues from making contact with the root during healing. ${ }^{5-9}$ The membrane gives preference to cells arising from the periodontal ligament to form a new connective tissue attachment to the denuded root surface. ${ }^{10}$ Animal studies and clinical trials in humans have documented the benefits of GTR procedures in achieving different degrees of periodontal regeneration. ${ }^{8,11-14}$

Different methods based on clinical, radiographic or histological measurements have been 
used in the evaluation of the outcomes of periodontal regeneration. 3,9,15-18 However, none of the methods used for human material incorporates quantitative $\mathrm{X}$-ray microanalysis to assess the degree of mineralization of the regenerated periodontal hard tissues. ${ }^{19}$

The application of electron probe X-ray microanalysis (EPMA) to hard tissues constitutes one of the most productive tools in the study of mineralization processes. ${ }^{20-22}$ Scanning electron microscopy (SEM) and the associated microanalytical systems have been advocated as an excellent approach to obtain information on mineralized tissues, not only in relation to morphofunctional features, but also in terms of mineral density and quantification that are factors closely associated with the mineralization index. ${ }^{18-20}$ This case report presents a localized aggressive periodontitis patient ${ }^{23}$ in which a localized infrabony defect was treated with GTR. A surgical re-entry was performed 3 years after surgery due to the need of an additional surgical intervention for orthodontic reasons. A small hard tissue biopsy was taken from the regenerated site and analyzed. A quantitative approach to EPMA to determine the concentration of calcium and phosphorus, the main elements in biomineralization, was used. Quantitative EPMA procedures and the different types of standards used for biological specimens have been frequently revised and due to methodological problems, ${ }^{24,25}$ these approaches

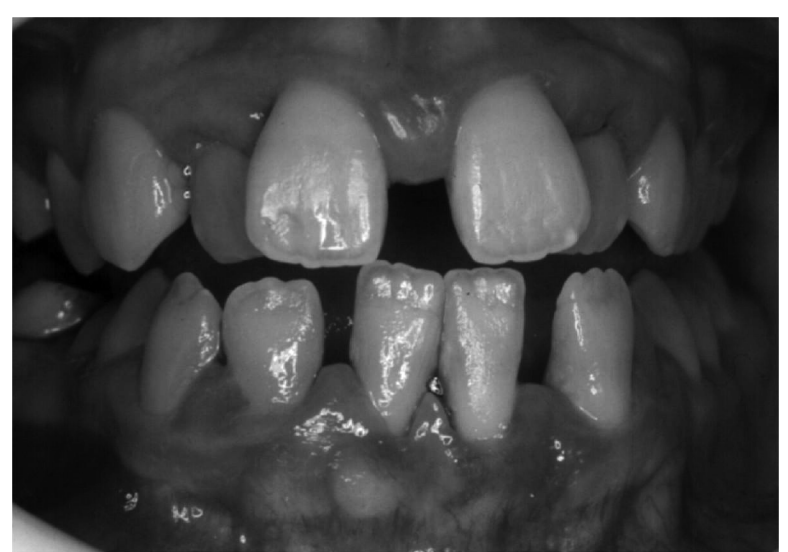

Figure 1. Initial clinical appearance before treatment.

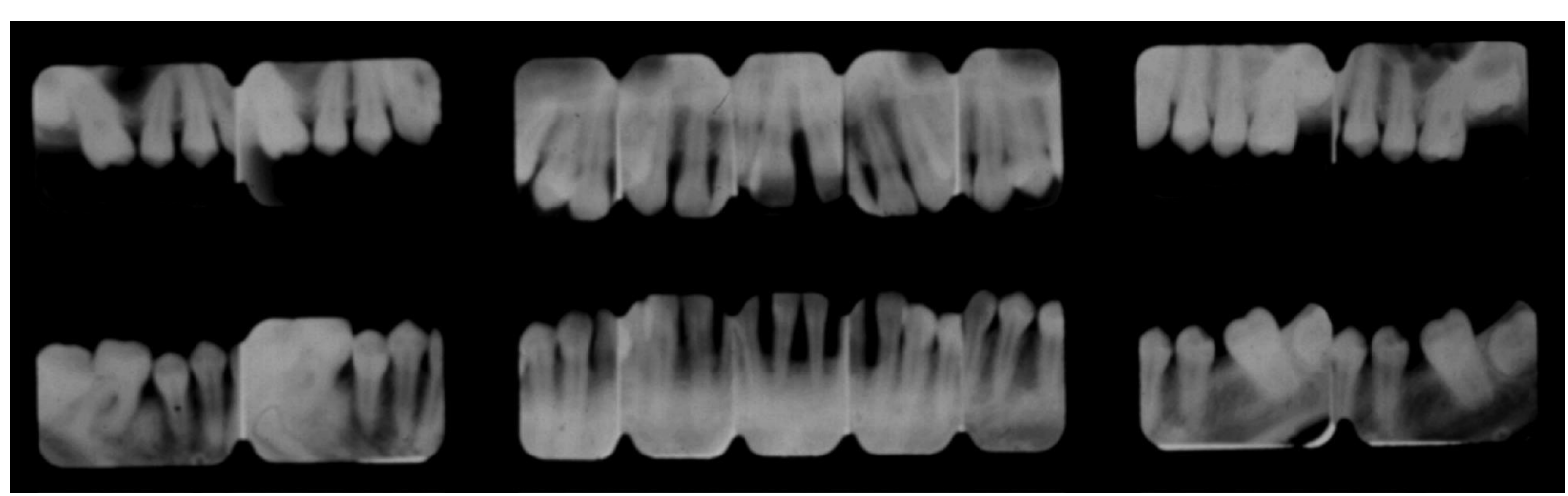

Figure 2. Radiographic images of the periapical region before treatment.

\section{MATERIAL AND METHODS}

A 13-year-old female patient with clinical features of localized aggressive periodontitis (no involvement of more than 3 teeth apart from central incisors and first molars) was referred for periodontal treatment to the Department of Periodontology, University of Granada (Figures 1 and 2). The patient reported no systemic diseases and a family history of periodontitis.

Initial treatment plan included motivation and oral hygiene instructions together with several sessions of scaling and root planning under local anesthetic. In addition, oral tetracycline $11 \mathrm{~g}$ daily for 21 days) was prescribed as an adjunctive systemic medication to mechanical periodontal treatment. At re-evaluation and when the patient demonstrated acceptable proficiency in plaque control procedures as determined by an O'Leary plaque record score of $8 \%,{ }^{26}$ surgical therapy was initiated at residual periodontal pockets.

A regenerative procedure by means of GTR was applied to teeth 31, 32, 41 and 42. A full mucoperiosteal flap was raised on the facial and lingual surfaces of all mandibular incisors to gain access for debridement of the granulation tissue and the root surfaces (Figure 3). Then, according to the principles of GTR described by Gottlow et $\mathrm{al}^{12}$ expanded polytetrafluoroethylene membranes (PTFE, Gore periodontal material, Gore-Tex, W.L. Gore and Assoc, Inc., Flagstaff, AZ, USA) were adjusted to cover the defects in the anterior-inferior area (teeth $31,32,41,42$ ). The membranes were removed 5 weeks after installation. Three years after the surgery, the inferior labial frenulum was surgically removed for orthodontic and periodontal reasons; during this surgical session a biopsy of hard tissue was taken between teeth 31 and 41 with a high speed $700 \mathrm{~L}$ bur under constant irrigation. Probing pocket depth in the lower incisors was determined with the aid of an acrylic stent. ${ }^{27}$ 
The probe was passed vertically through a hole in the stent to locate the base of the defect between the teeth. The tissue biopsy was obtained from the point of new bone formation indicated by the probe and stent (from the alveolar bone in contact with the root surfaces of teeth 31 or 41 at the point indicated by the stent). ${ }^{28}$

The specimen was cryofixed in liquid $\mathrm{N}^{2}$-cooled Freon ${ }^{22}$ and freeze-dried at $-80^{\circ} \mathrm{C}$ for $48 \mathrm{~h}$ in a Polaron Freeze-drier apparatus. The specimen was sputter-coated with carbon in an argon atmosphere ( $P=0.1$ torr) and studied in a 505 Philips SEM scanning electron microscope lvoltage $=$ $15 \mathrm{kV}$; spot size $=50 \mathrm{~nm}$; tilt angle $=35^{\circ}$; take-off angle $=50^{\circ}$ ). An EDAX PV9900 was used for the microanalysis (count rate $=1200$ counts per s; live time $50 \mathrm{~s}$ ). Spectra were collected by pin-point electron beam at 40000x. The peak-to-background $(P / B)$ ratio method ${ }^{29,30}$ was used to measure the concentrations of calcium and phosphorus. Ten analyses were done. Microcrystalline salt standards were used to quantify $\mathrm{Ca}$ and $\mathrm{P}$ as described in previous publications:22,31-36 $\mathrm{Ca}_{3} \mathrm{O}_{8} \mathrm{P}_{2}, \mathrm{Ca}(\mathrm{OH})_{2}$, $\mathrm{Ca}\left(\mathrm{H}_{2} \mathrm{PO}_{4}\right)_{2} \cdot \mathrm{H}_{2} \mathrm{O},\left(\mathrm{CH}_{3}-\mathrm{COO}\right)_{2} \mathrm{Ca}, \mathrm{CaHPO} \cdot 2 \mathrm{H}_{2} \mathrm{O}$, $\mathrm{CaCO}_{3}, \mathrm{Ca}\left(\mathrm{H}_{2} \mathrm{PO}_{4}\right)_{2}, \mathrm{CaHPO}_{4}, \mathrm{Ca}_{2} \mathrm{P}_{2} \mathrm{O}_{7}, \mathrm{C}_{6} \mathrm{H}_{11} \mathrm{O}_{7} \cdot 1 / 2 \mathrm{Ca}$, $\mathrm{C}_{12} \mathrm{H}_{21} \mathrm{O}_{12} \cdot 1 / 2 \mathrm{Ca}, \mathrm{PO}_{4} \mathrm{HK}_{2}, \mathrm{C}_{28} \mathrm{H}_{56} \mathrm{NO}_{8} \mathrm{P}, \mathrm{P}_{2} \mathrm{O}_{7} \mathrm{Sn}_{2}$ and $\mathrm{C}_{52} \mathrm{H}_{104} \mathrm{NO}_{8} \mathrm{P}$. The standards were cryofixed in liquid $\mathrm{N}_{2}$, freeze-dried and sputter-coated as described above, and analyzed in the microscope immediately after preparation to avoid contamination or chemical modification. The concentration of element $x$ in the specimen $\left(\mathrm{Cx}_{\mathrm{sp}}\right)$ was calculated according to the formula:

$$
C x_{s p}=\frac{(P / B)_{s p}}{(P / B)_{s t d}} \cdot \frac{\left(Z^{2} / A_{s p}\right)}{\left(Z^{2} / A_{s t d}\right)} \cdot C x_{s t d}
$$

where $\mathrm{Cx}$ is the concentration of the element in weight percent, $\mathrm{P} / \mathrm{B}$ is the peak-to-background ratio for the element, the subscripts sp and std refer to the specimen and standard respectively, and the value of $Z^{2} / A$ is the mean value of the atomic number squared and divided by the atomic weight of the sample. ${ }^{25,32}$

\section{RESULTS}

In the course of frenulectomy three years after GTR, surgical access to the regenerated hard tissues was possible. The most noteworthy anatomical observation was the presence of a continuous band of hard tissue surrounding the roots of the incisors (teeth 31, 32, 41, 42) (Figure 3). Clinical parameters had improved significantly as compared with the baseline values. Mean baseline attachment losses were 6-9 $\mathrm{mm}$ in lower incisors, with the greatest loss in 31 , with initial defects presenting a depth of $4-5 \mathrm{~mm}$ on the mesial and distal aspects of the affected teeth, preserving the buccal and lingual bone walls. At three years, there were attachment losses of $2 \mathrm{~mm}$ in 32 and 41 and of $4 \mathrm{~mm}$ in 31 ; the probing depths in bone defects at previously reported sites ranged from 0.5 to 1 $\mathrm{mm}$, with increased thickness of the buccal plate. After frenulectomy and coronal replacement of the soft tissue flap, adequate attached gingiva was obtained.

The P/B values obtained from the ten microanalyses of the regenerated tissue specimens are given in Table 1. All spectra showed significant peaks for calcium and phosphorus, with smaller peaks for sulfur. Quantitative analyses with the approach described in material and methods yielded weight fraction values in \% between 1.98 and 14.03 for calcium concentrations, and between 1.57 and 7.68 for phosphorus. Mean weight fraction values of ten determinations in $\%$ were 6.35 for calcium and 4.14 for phosphorus (Table 1). The Ca/P mass ratio, calculated from the mean values of $\mathrm{Ca} / \mathrm{P}$ for each analysis, was 1.49+0.38.

\section{DISCUSSION}

The methods used to evaluate newly-formed hard tissue in periodontal regeneration with GTR techniques include clinical examination, radiographic assessment, and histological evaluation. ${ }^{3}$ These approaches, particularly histological procedures, are of use in evaluating and measuring the

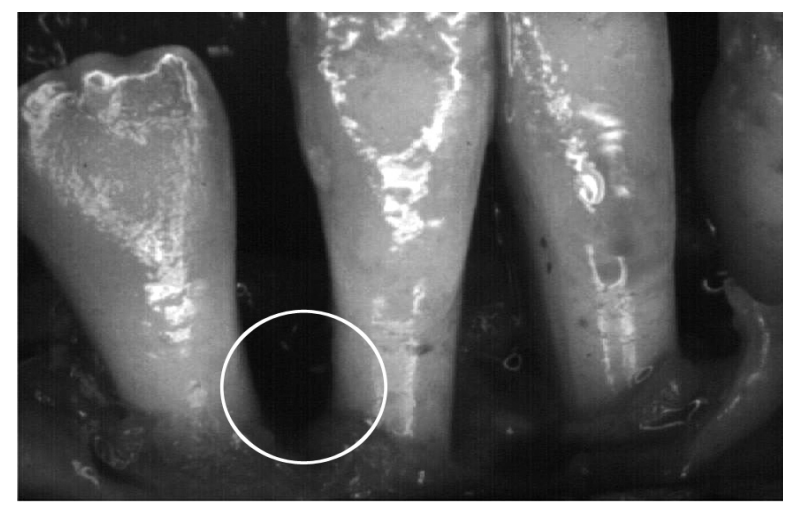

Figure 3. Antero-inferior zone during flap surgery for GTR Note bone defects around teeth.

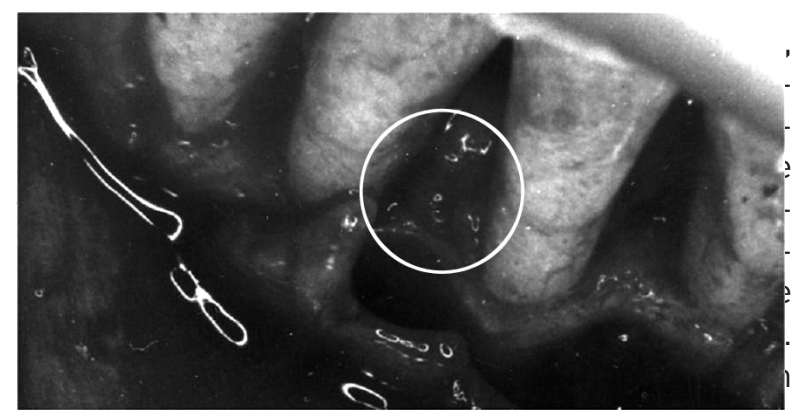

Figure 4. Antero-inferior zone three year after GTR. Note band of regenerated bone around the initial defects. 
Table 1. Microanalysis of ten pin-point spectra (M) of newly regenerated hard tissue, expressed as \% weight fraction (WF) of $\mathrm{Ca}$ and $\mathrm{P}$, and $\mathrm{Ca} / \mathrm{P}$ ratio.

\begin{tabular}{lccccccccccccc}
\hline Element & $\begin{array}{c}\text { Microanalytical } \\
\text { data }\end{array}$ & M1 & M2 & M3 & M4 & M5 & M6 & M7 & M8 & M9 & M10 & X \\
\hline $\mathrm{Ca}$ & $\mathrm{C}_{\mathrm{Ca}}$ (WF) & 2.988 & 4.825 & 1.977 & 12.629 & 7.113 & 3.336 & 3.877 & 8.251 & 14.031 & 4.487 & 6.351 \\
$\mathrm{P}$ & $\mathrm{C}_{\mathrm{P}}$ (WF) & 2.419 & 4.142 & 1.569 & 7.117 & 3.930 & 2.022 & 5.467 & 4.542 & 7.681 & 2.554 & 4.144 \\
$\mathrm{Ca} / \mathrm{P}$ & $\mathrm{C}_{\mathrm{Ca}} / \mathrm{CP}$ & 1.235 & 1.164 & 1.260 & 1.774 & 1.809 & 1.649 & 0.709 & 1.816 & 1.826 & 1.756 & 1.499 \\
\hline
\end{tabular}

for EPMA has been verified in other mineralized tissues. ${ }^{32,33}$ Cryofixation followed by freeze-drying avoids ionic redistribution, and provides tissue samples in which the elemental composition is as close as possible to that observed in living tissue. ${ }^{25}$

Quantitative X-ray microanalysis in biological samples has been performed by the $P / B$ ratio method using standards made with $20-25 \%$ gelatin or dextran, to which salts containing the elements of interest have been added. ${ }^{24,33}$ However, this type of standard is unsuitable for the analysis of mineralized tissues because the standards differ markedly from the specimens with respect to matrix composition. For this reason, we chose salt microcrystals containing $\mathrm{Ca}$ or $\mathrm{P}$ as our standards to estimate $\mathrm{Ca}$ and $\mathrm{P}$ percent weight in newlyformed tissue. Crystal salt standards offer several advantages: they are quick and easy to prepare, their composition is known, and their crystalline structure guarantees a constant relationship between the elements, regardless of the area of analysis. $^{32}$

The P/B ratio method ${ }^{29,30}$ differs from Hall's continuum normalization method, ${ }^{37}$ which is generally used to quantify thin biological specimens. The P/B method records the background at the same energy as the characteristic peak, instead of the background from a selected region of the continuum (usually 4.2-6.2 kV). The principle of this method is that the concentration of an element in the area of analysis in the specimen is proportional to the net counts in the characteristic peak of that element, divided by the continuum under the peak. The proportionality constant, $k$, is characteristic for each element, and can be determined by analysis of standards in which the concentration is known. The value of the $P / B$ method is that it is independent of absorption and specimen surface effect, and is, therefore, suitable for rough surfaces and variations in beam current intensity. ${ }^{35,36,38}$

Data obtained with the methods discussed above show the presence of high concentrations of calcium and phosphorus in the newly formed bone after three years of healing. The $\mathrm{Ca} / \mathrm{P}$ mass ratio of 1.53 found in our quantitative study was strongly suggestive of the presence of a hydroxyapatite structure in the regenerated hard tissue.
The $\mathrm{Ca} / \mathrm{P}$ molar ratio in young bone undergoing mineralization is usually less than 1.67 , i.e., the ideal stoichiometric molar ratio. ${ }^{39}$

\section{CONCLUSIONS}

Within the limitations of this report, the novel application of quantitative EPMA to periodontology may be a useful tool that can provide an accurate assessment of the degree of mineralization in an extremely small tissue sample. Thus, it could be suggested as an additional method to evaluate treatment outcomes in future regenerative periodontal research.

\section{ACKNOWLEDGEMENTS}

We thank Mrs. María Angeles Robles for her competent technical assistance and we express our gratitude to Dr. Javier Carreño for his effort in the development of this study. We also show our appreciation to Dr. Adrian Guerrero for revising the manuscript.

\section{REFERENCES}

1. American Academy of Periodontology. Glossary of Periodontal Terms 4th Edition. Chicago, Illinois: The American Academy of Periodontology; 2001:44.

2. Isidor F, Karring T, Nyman S, Lindhe J. New attachmentreattachment following reconstructive periodontal surgery. J Clin Periodontol 1985;12:728-735.

3. Lynch SE. Methods for evaluation of regenerative procedures. J Periodontol 1992;63:1085-1092.

4. Isaka J, Ohazama A, Kobayashi M et al. Participation of periodontal ligament cells with regeneration of alveolar bone. J Periodontol 2001;72:314-323.

5. Marks SC Jr, Miller SC. Local delivery of prostaglandin E1 induces periodontal regeneration in adult dogs. $J$ Periodontal Res 1994;29:103-108.

6. RipamontiU, Reddi AH. Tissue engineering, morphogenesis, and regeneration of the periodontal tissues by bone morphogenetic proteins. Crit Rev Oral Biol Med 1997;8: 154-163.

7. Murakami S, Takayama S, Ikezawa K et al. Regeneration of periodontal tissues by basic fibroblast growth factor. $J$ Periodontal Res 1999;34:425-430.

8. Karring T. Regenerative periodontal therapy. J Int Acad Periodontol 2000; 2:101-109.

9. Cochran DL, King GN, Schoolfield J, Velasquez-Plata D, Melloning JT, Jones A. The effect of enamel matrix proteins on periodontal regeneration as determined by histological analyses. J Periodontol 2003;74:1043-1055.

10. Pontoriero R, Lindhe J, Nyman S, Karring T, Rosenberg E, Sanavi R. Guided tissue regeneration in degree II furcation involved mandibular molars. J Clin Periodontol 1988;15: 247-254. 
11. Aukhil I, Pettersson E, Suggs C. Guided tissue regeneration. An experimental procedure in beagle dogs. $J$ Periodontol 1986;57:727-734.

12. Gottlow J, Nyman S, Lindhe J, Karring T, Wennstrom J. New attachment formation in the human periodontium by guided tissue regeneration. Case reports. J Clin Periodontol 1986;6:604-616.

13. Mardas N, Kostopoulos L, Stavropoulos A, Karring T. Osteogenesis by guided tissue regeneration and demineralized bone matrix. J Clin Periodontol 2003;30:176183.

14. Silvestri M, Sartori S, Rasperini G, Ricci G, Rota C, Cattaneo V. Comparison of infrabony defects treated with enamel matrix derivative versus guided tissue regeneration with a nonresorbable membrane. J Clin Periodontol 2003;30: 386393.

15. Christgau M, Schmalz G, Reich E, Wenzel A. Clinical and radiographical split-mouth-study on resorbable versus non-resorbable GTR-membranes. J Clin Periodontol 1995; 22:306-315.

16. Lekovic V, Klokkevold PR, Kenney EB, Dimitrijelic B, Nedic $M$, Weinlaender M. Histologic evaluation of guided tissue regeneration using 4 barrier membranes: a comparative furcation study in dogs. Periodontol 1998;69:54-61.

17. Unsal B, Ozcan G, Tuter G, Kurtis B, Yalim M. Evaluation of initial attachment of human gingival fibroblast cells to biodegradable membranes in vitro by light and scanning electron microscopy. J Oral Sci 1999;41:57-60.

18. Schantz JT, Hutmacher DW, Ng KW, Khor HL, Lim MT, Teoh SH. Evaluation of a tissue-engineered membranecell construct for guided bone regeneration. Int J Oral Maxillofac Implants 2002;17:161-174.

19. Campos A, González-Jaranay M, Moreu G, SánchezQuevedo MC. Electron microprobe analysis in periodontal guided tissue regeneration. Cell Biol Int 1993;17:695-696.

20. Boyde A, Maconnachie E, Reid SA, Delling G, Mundy GR. Scanning electron microscopy in bone pathology: review of methods, potential and applications. Scann Electron Microsc 1986;4:1537-1564.

21. Sánchez-Quevedo MC, Crespo PV, García JM, Campos A. Xray microanlytical histochemistry of human circumpulpar and mantle dentine. Bone Miner 1989;6:323-329.

22. Zambrano M, Nikitakis NG, Sanchez-Quevedo MC, Sauk JJ, Sedano H, Rivera H. Oral and dental manifestations of vitamin D-dependent rickets type I: Report of a pediatric case. Oral Surg Oral Med Oral Pathol Oral Radiol Endod 2003; 95:705-709.

23 Armitage GC. Development of a classification system for periodontal diseases and conditions. Ann Periodontol 1999;4:1-6.

24. Warley A. Standards for the application of X-ray microanalysis to biological specimens. $J$ Microscopy 1990;157:135-147.

25. Warley A. X-ray microanalysis for biologists. London: Portland Press; 1997.

26. O'Leary TJ, Drake RB, Naylor JE. The plaque control record. J Periodontol 1972;43:38.

27. Clark DC, Chin Quee T, Bergeron MJ, Chan EC, LautarLemay C, de Gruchy K. Reliability of attachment level measurements using the cementoenamel junction and a plastic stent. J Periodontol 1987;58:115-118.

28. Bowers GM, Chadroff B, Carnevale R et al. Histologic evaluation of new attachment apparatus formation in humans. J Periodontol 1989;60:664-674.

29. Statham PJ, Pawley JB. A new method for particle X-ray microanalysis on peak to background measurements. Scann Electron Microsc 1978;1:469-478.

30. Small JA, Heinrich KFJ, Newbury DE, Myklebust RL. Progress in the development of the peak-to-background method for the quantitative analysis of single particles with electron probe. Scann Electron Microsc 1979;11:807-816.

31. Campos A, Rodríguez IA, Sánchez-Quevedo MC, García JM, Nieto-Albano OH, Gómez de Ferraris ME. Mineralization of human premolar occlusal fissures. A quantitative histochemical microanalysis. Histol Histopathol 2000;15: 499-502.

32. López-Escámez JA, Crespo PV, Cañizares F, Campos A Standards for quantification of element in the otolithic membrane by electron probe $\mathrm{x}$-ray microanalysis: calibration curves and electron beam sensitivity. $J$ Micros 1993;171:215-222.

33. López-Escámez, JA, Cañizares FJ, Crespo PV, Baeyens JM, Campos A. Electron probe microanalysis of gentamicininduced changes on ionic composition of the vestibular gelatinous membrane. Hear Res 1994;76:60-66.

34. López-Escámez JA, Campos A. Standards for X-ray microanalysis of calcified structures. Scann Electron Microsc 1994;8:171-185

35. Sánchez-Quevedo MC, Ceballos G, García JM, Rodríguez IA, Gómez de Ferraris ME, Campos A. Scanning electron microscopy and calcification in amelogenesis imperfecta in anterior and posterior human teeth. Histol Histopathol $2001 ; 16: 827-832$.

36. Sánchez-Quevedo MC, Ceballos G, Garcia JM, Luna JD, Rodriguez IA, Campos A. Dentine structure and mineralization in hypocalcified amelogenesis imperfecta: a quantitative X-ray histochemical study. Oral Dis 2004;10:9498.

37. Hall TA, Anderson HC, Appleton TC. The use of thin specimens for X-ray microanalysis in biology. J Microsc 1973;99:177-182.

38. Armstrong JT. Quantitative elemental analysis of individual microparticles with electron beam instruments. In: Heinrich KFJ, Newbury DE, eds. Electron probe quantitation. New York: Plenum Press, 1991:261-315.

39. Glimcher MJ. The nature of the mineral component of bone and the mechanism of calcification. In: Coe FL, Favus MJ, eds. Disorders of bone and mineral metabolism. New York: Raven Press. Ltd, 1992:265-286. 